\title{
Learning for Professional Development of Social Studies Teachers in Thailand
}

\author{
Khwandaw Pinthongpunth ${ }^{1, *}$, Thongchai Phuwanatwichit ${ }^{2}$, Charin Mangkhang ${ }^{1} \&$ Atchara Sarobol $^{2}$ \\ ${ }^{1}$ Faculty of Education, Chiang Mai University, Thailand \\ ${ }^{2}$ Faculty of Humanities and Social Sciences, Chiang Mai University, Thailand \\ *Corresponding author: Faculty of Education Chiang Mai University, Thailand. E-mail: Khwandaw22@yahoo.co.th
}

Received: December 5, $2020 \quad$ Accepted: February 19, $2021 \quad$ Online Published: May 18, 2021

doi:10.5430/jct.v10n2p58 URL: https://doi.org/10.5430/jct.v10n2p58

\begin{abstract}
The research of creative learning for professional development of social studies students aims to study the basic information on creative learning management models for teacher professional development for Social Studies Program students. There are various ways to learn. The model that can be developed and applied to learners to develop the knowledge, skills and competencies necessary for the management of teaching and learning in the modern era to support learners and teachers in the rapid changing society, environment, economy and technology that have an impact on learning and teaching. The teachers who have a teaching method that can pass on or develop the learners is the first factor that generate the understanding between teachers and students. It is to understand the basic information of the local educational institutions. Therefore, this article provides basic information on creative learning management for teacher professional development for students studying in Bachelor's degree in Social Studies Program, Songkhla Rajabhat University, the local university where produces graduates serve to society and communities. Therefore, this article can create an understanding and a basis for further research work.
\end{abstract}

Keywords: creative learning management, social studies teacher professional development, teaching

\section{Introduction}

Education plays a crucial role in human development. The quality of human resource is the most valuable that is necessary to develop. The desirable qualities to be able to live normally in the society and up to date in various situations, which are changing rapidly in the modern world. Therefore, it is inevitable to change the way of teaching and learning to be in line with trends in the current world (Department of Academic Affairs, 2009). According to individual learners' interest and group learning in reality from community and nearby resources, they will enable learners to create knowledge on their own. The local learning resources will support learners with direct experience. They will be able to understand lessons easily, realize the value of environment in their daily life, and conserve their local. The teacher can design learning activities in accordance with the learning content of the core curriculum and prepare at the local learning resources. Therefore, professional learning is a group with the same goal with an exchange of knowledge on the issues of individual interest. The continual development of education aims to continuously achieve acquisition and development for knowledge. The Continuous Quality Improvement (CQI) is a continuous process that teachers and learners work together in a cycle by questioning and doing action research in order to achieve better learning outcomes. It is believed that the principle of better students' learning development depends on teachers and educators' work (Wichan Panich, 2012). In consequence, the education develops individual, social, and nation through teaching and learning management using community-based learning resources based on Constructivist Theory under active process condition. This condition occurs individually based on learners' creations by themselves by mixing newly received information with the existing information including previous experiences to create learning on their own. The learners' experiences will be used in decision-making and directly result in new knowledge creation, new idea or learning. In general, the learning process is a characteristic of learners' creations through problem solving together with others under following five basic principles (Sumalee Chaicharoen, 2014 ): 1. Problem based, 2. Resource, 3. Scaffolding, 4. Coaching, and 5. Collaboration.

Teacher professional development is a method and strategy that allows teachers to learn and perform work for further 
development, since good teaching is not generated within a short time. In addition, the lack of action, open-mindedness, adaptation, development, and applicability including incomplete comprehensive learning experience provided in teacher education institutions. Currently, the future production of teachers supporting other organizations must be developed and responded to society and communities in the first priority. Since graduates from Rajabhat Teacher Institutes are provided for local teachers, I would like to present the basic information regarding creative learning for professional development of social studies teachers in this article.

\section{Background of the Problem}

The development of teacher training institutes in Thailand referring to a case study of Moon Teacher Training School. Then, it has been devloped to Songkhla Teachers College, Songkhla Rajabhat Institue and the Faculty of Education in 2004-2018 (5-year curriculum), Social Studies Program, Songkhla Rajabhat University in the present. It is one of the oldest institutions in Thailand in the south region, which was established in 1919. By that time, it had produced county teachers to work as primary school teachers and then county teacher training schools were established. The graduates from this course were called the county certificate teachers. Later, there was an act on the Administration of the Kingdom of Siam, B.E. 2476 (1933) defined to terminate the division of counties. The county teacher training schools were changed to a certificate teacher training schools. Later, it was raised to be Songkhla Teachers College on May $1^{\text {st }}$, 1961. After that, the government promulgated the Teachers College Act, B.E. 2518 (1975) and Songkhla Teachers College offered Bachelor degrees in Education. Later in 1984, the government promulgated the Teachers College Act, B.E. 2527 (1984) for teachers college to produce teachers and offer professional courses as local requirement and necessities. Therefor, Songkhla Teachers College started to produce teachers at the bachelor's degrees in education and other professional certificates as aforementioned reasons on February $14^{\text {th }}$, 1995. His Majesty King Bhumibol Adulyadej (King Rama 9 or His Majesty King Bhumibol Adulyadej The Great, in the present) officially bestowed name "Rajabhat" for teachers college and later Songkhla Teachers College was changed its name to "Songkhla Rajabhat Institute". It had been developed and offered at the graduate level in 2001. Consequently, it was raised as Songkhla Rajabhat University on June 15 $5^{\text {th }}, 2004$ until present. It offered curriculums in bachelor's and master's degrees. The seven bachelor's degree curriculums consisted of Faculties of Education, Faculty of Agricultural Technology, Faculty of Humanity and Social Sciences, Faculty of Management Sciences, Faculty of Science and Technology, Faculty of Fine and Applied Arts, and the Faculty of Industrial Technology. Faculty of Education was one of the faculties which had produced teachers. Currently, this faculty offers 8 professional programs in bachelor's degrees in Mathematics, General Science, Thai Language, Social Studies, English, Physical Education, Special Education (in Thai) and Early Childhood Education. Moreover, this faculty offers 2 programs in master's degrees in Educational Administration and Curriculum and Instruction. This study focuses on Social Studies Program, since it has continuously produced social studies teachers and has collaborated with several faculties, i.e. Faculty of Humanities and Social Sciences, Faculty of Management Sciences, and Faculty of Education. In 1999, the Social Studies Program was affiliated under the Faculty of Humanities and Social Sciences (4-year curriculum) offered 9 programs and 6 of them were in education programs. Later, in 2003, the students of Education were changed to affiliate in the Faculty of Education. However, on the aspect of administration, lecturers in all programs related to specific subjects still remained with the Faculty of Humanities and Social Sciences.

In 2004, the Ministry of Education adjusted the curriculum of teachers' production from 4 years to 5 years. Therefore, it was the first time that Songkhla Rajabhat University had adopted the policy to start producing 5-year curriculum teachers with 4 academic years of learning and 1 academic year for teaching practice. The Social Studies Program was a program that changed duration, course structure, responsible person, and affiliations. After that, the curriculum was revised in 2006 to improve teachers' production to be in accordance with the purpose of the National Education Act, B.E. 2542 (1999) due to the following reasons:

Regarding the General Education courses, they were divided from sets into courses and added some courses in order to provide students with complete knowledge in 4 skills: language and communication, human sciences, social sciences, mathematics, and science and technology. For instance, Thai Language Communication, Human and Society, Life with Science and Technology were added in revised curriculum B.E. 2547 (2004). For the revised curriculum B.E. 2549 (2006), it was added Thai Language for Communication 1 and Philosophy and Religion.

Regarding the Teacher Profession courses, the codes and course descriptions were changed to be in accordance with the attributes of the learners to practice teaching profession in schools. The goal was to provide learners with good skills and attitudes for teaching practice preparation. In addition, there was is a change from sets into courses 
with clearer content. Also, Learning Management was set as basis of the course.

Regarding the Specific Requirement courses, the codes and course descriptions were changed to be clearer and adjusted the credit ratio to be in accordance with the attributes of the courses and curriculum structures. For instance, Analytical Geography course in 2004 was changed in 2006 to Physical Geography, World Regional Geography, Analytical Geography of Thailand, and Human Geography, etc.

Later, in 2009-2013, the curriculum was revised to be suitable until the end of the 5-year curriculum. The revision was in 2015 and started using in 2016 to 2018. The final phrase revision of 5-year curriculum was mainly improved on the major courses of Geographic, and History by adding and removing courses that were inconsistent with Thailand and international. The Multicultural course was added in order to be consistent with the local of Songkhla Rajabhat University and the schools provided for teaching practice and government social studies teachers. In contrast, some students graduated in each academic year found that they didn't want to work as teachers or social studies teachers as $30 \%$ of them chose other career paths. As shown in the past five years, social studies students graduated in 2014-2019 gave feedback to Social Studies Program on teaching and learning that it should be applied in other professions for future employment. Therefore, the problem and background of this research was to study the general information of the Social Studies Program of Songkhla Rajabhat University that provided 5-year curriculum (2011-2018) and 4-year curriculum (2019-present) and produced quality graduates for local and society under community-based creative learning management to meet the community's need and in line with the social studies teacher professional capacity in the future.

\section{Theory and Method}

On the aspect of classroom management of this institute, its learning management has continuously developed to be in accordance with the community and local's need by linking the local context with the future in order to produce quality teachers. In the past, the Social Studies Program (5-year curriculum) 2016-2018 had organized learning in the practical and theoretical models through practical and theoretical lessons in order to prepare general knowledge before stepping to the practice session. These models were in General Education courses in both language and communication courses, Humanities and Social Sciences courses, Mathematics courses, and Science and Technology courses. In addition, Specific Requirement courses, i.e. Teacher Profession courses and major courses. This is consistent with theoretical concept of Steiner (Steiner E 1988) in term of learning management which is divided into two medels as follows:

1. The practical model or model-of is a kind of physical model, such as car model, plane model, and model picture.

2. The theoretical model or model-for is a kind of model building based on a theoretical conceptual framework. The theory is not a pattern or a model, but it supports the related structured model.

The researchers have studied concepts and the main theories in experiential learning management model creation to create various aspects of the model consisted of Constructivism Theory, Information Processing Theory, Roger's Self Theory, and Collaborative Learning Theory as follows:

1. The Constructivism Theory claims that humans generate knowledge from surroundings because they have the potential to generate it from real experience (Richardson 1997). The reasonable knowledge generation consists of 4 elements:

1.1 Humans can generate knowledge themselves. The theory claims that humans have the potential to generate their own knowledge and understanding as Epistemology Concept. It believes that the existence of external things is unacceptable and they are separated from human perception. The knowledge belongs to knowers, not outside. Humans have to interact with things and use their prior knowledge and experience to create meaningful new experiences.

1.2 Humans generate knowledge well when interacting with the environment. The realistic environment allows humans to generate knowledge more in real conditions than those created or simulated conditions. They can apply the generated knowledge to explain or understand the real surroundings. So, that knowledge is truly valuable and will be remembered for a long time.

1.3 Knowledge is interdisciplinary in real-world situations when humans interact with the environment. Humans' point of views on environment are: self, other person, society, culture, economy, science and others. In the reality, learners will be involved in knowledge in various academic disciplines simultaneously without any specific separation as they are at school. 
1.4 Knowledge is developed by team working. Humans live together as a society and interact with each other in thinking and action. Therefore, when each human generates knowledge from his interaction with the environment, individual knowledge is vary based on prior knowledge and experience. They have ability to interpret when they exchange knowledge, understanding, and thinking to others. Human potential makes them assess knowledge, understanding of themselves and others, then adjust their prior knowledge to be more reasonable based on similarities and differences. Moreover, they eliminate conflicts and balance knowledge (Richardson virgimia, 1997). In conclusion, according to the attributes of Constructivism Theory, the learners generate knowledge and understanding themselves and learn new things based on prior knowledge and existing understanding. Furthermore, social interaction is essential to learning. The learners can learn meaningfully from the environmental arrangement and activities that are similar to real life.

2. The Information Processing Theory of Klaus Meier (Klaus Meier, H. J. 1985), explains human learning by comparing computer function to brain function. Their functions run step by step, i.e. input data via device or receiver, encoding by using instruction set or software, output data via the device. This theory is useful for applying learning management model in many ways as follows:

1. Recognition affects the perception of something. Humans recognize things and store it in the memory. Providing familiar stimulation for the learner can help the learner pay attention and recognize it. Therefore, the teacher can connect to something new with that.

2. Attention is an essential element to perceive information into short-term memory. Therefore, stimulations should be provided as learners' interests in learning management because it helps the learners pay attention, recognize, and store them into short-term memory.

3. As previous recognized information is stored in short-term memory, so it can be stored longer by using various methods, such as repeating or organizing things into categories in order to remember it easily.

4. Learners can store long-term memory by encoding. This can be performed in various ways, such as repeating, reviewing, or elaborative operations processes including composing, integrating, expanding, and correlating new knowledge with existing knowledge.

5. Data stored in short-term or long-term memory can be called out via "Effectors". They induce verbal behavior or action which allow a person to express inner thoughts as observable behaviors. However, the inability to utilize stored information may be due to the inability to retrieve the information to the conscious level or forgetfulness.

6. According to brain processes, they are regulated by another control unit, which is comparable to the operating program as "Software" of the computer. Therefore, learners can manage cognitive or thinking processes, they can command the brain to act and achieve their learning.

3. Roger's Self Theory (Rogers, 1969), they researchers found that humans can improve themselves better in relaxed and independent situations by providing relaxing and conducive learning environment focusing on student-center. The teachers use non-directive teaching method and facilitate learning for learners. Learners can learn better by using process learning based on teaching principle, such as providing comfortable, safe, and reliable learning environment. Individual learner has the potential and motivation to develop on his own, so teachers should teach without instruction and allow learners to guide in self-learning. In addition, teachers can help learners until they achieve by focusing on the process learning because it is an important tool that a person uses to live and seek further knowledge.

4. Theory of Collaborative Learning, Thaina Khaemmanee claims in the teaching book (Thaina Khaemmanee, 2011) that it is group learning of 3-6 learners with different abilities and help each other learn to achieve the goal. In addition, David Johnson said that there are three kinds of interaction: 1. Competitive learning: each learner will try to learn better than others in order to get a good score and be praised or receive various compensation, 2. Individual learner: each learner is responsible for taking care of himself without association with others, and 3. Cooperative learning: each learner is responsible on his own and helps others at the same time. However, these theories can be applied by: 1. Determining the aim of the lesson both in knowledge and various process skills, 2. Setting size of the group to be 3-6 people (4 is the most suitable), 3. Randomizing learners into group by considering gender, ability, and aptitude, 4. Defining the role of each group member to help learners interact closely and participate in work, 5. Organizing places, content, material or work for learners to do clearly, 6. Advising closely by teachers, 7. Observing group work and assist the group as appropriate, and 8 . Evaluating both qualitative and quantitative learning outcomes using various methods.

According to the observation and interview with teachers of the Faculty of Education and others who produced co-teaching major subjects (5-year curriculum), the different and similar methods were used in teaching. Every 
teacher focused on each profession, for example, the professional teacher emphasized on teacher characteristics both in theorical and practical content, while the major teachers focus on practical content. However, both teachers had their own teaching style which were consistent with various factors, such as Constructivism Theory, Information Processing Theory, Roger's Self Theory, and Collaborative Learning Theory. Furthermore, the researcher analyzed the Educational Management Innovation course by observing the teaching and interviewing from the lecturers. It was found that all students must be enrolled in the $4^{\text {th }}$ year in specific requirement courses and major courses code 1134505 Learning and Teaching Management for Social Studies 3(2-2-5). The course description of this subject is "Meaning, significance and scope of social studies learning management in the primary school level, learning theory and social studies teaching, learning models and development of teaching and learning models, principles and techniques, methods of social studies learning management, design of social studies learning experiences by integrating other subjects, media and social studies learning innovations, preparing social studies learning management plans, practical training for developing the competency of social studies learning management to become a social studies teacher". This is in line with the philosophy of Songkhla Rajabhat University that to provide for higher education institutions and local development. The vision of the Faculty of Education is to produce graduates for developing teachers and educational personnel for local development. The graduates of Songkhla Rajabhat University were obtained the returning teacher program for the year 2017. It was found that the returning teachers were $80 \%$ of the graduates of the faculty. The data of Social Studies Program revealed that 32 students in code 56E110 became 18 in returning teacher program. After these 18 graduates returned their own hometowns, it was found that they had problems in teaching and learning in Social Studies course. The problems were mainly in content management and could not applied teaching methods to the subject content. The graduates in waiting list were found to be contract teachers and self-employed, etc. This research method was to analyze the document, relevant texts and researches regarding creative experiential learning management. The sources were from the documents, relevant texts and researches in learning management, learning management model, creative experience, and etc. The document analysis form was used as an instrument to collect information, then analyzed obtained data and described.

\section{Discussion}

Reagarding the approaches for creative learning for practical teaching students development, educations have provided various meanings. As an example of education from Section 4 of the National Education Act, B.E.2542 (1999), it is defined as learning process of an individual and society transforming knowledge from practicing, training, cultural inheritance, academic progress creation, knowledge generation arising from the setting up of the social environment, learning and supporting factors for a person to learn continuously throughout his life. According to the provision of education in Thailand appearing in Section 15, there are three models of education management:

1) Formal education is a study that defines goals, methods, courses, duration of study, measurement and evaluation, which are certain conditions of graduation. Therefore, there are two levels of formal educations: basic education and higher education.

First, the basic education consists of education which is organized not less than twelve years prior to higher education. The classification and type of basic education are under the ministerial regulations.

Second, the higher education is the education after finishing secondary education, i.e. diploma, high vocational certificat, bachelor's degree, professional high-level technical teacher, and postgraduate level: master's and doctoral degrees.

2) Non-formal education is a flexible form in setting goals, models, methods, educational management, duration of study, measurement and evaluation, which are important conditions of graduation. The content and curriculum must be appropriate and in line with the problems and needs of each individual.

3) Informal education is an education that allows learners to learn by themselves according to their interests, potential, readiness and opportunities by studying from individuals, experiences, society, environment, materials or other knowledge sources.

Regarding the compulsory education management in Thailand, children aged 7-16 years must have a compulsory education as indicated in Section 17 to have a nine-year compulsory education. It allows children aged seven years to attend in basic schools until the age of sixteen, except they pass the test to level nine of compulsory education. The criterias and methods for counting age shall be as prescribed in the Ministerial Regulations. When completing the compulsory education. The path of education is three years in high school or professional level. After that, they can 
continue to study in higher education. The study found that the statistics of year 2015 from the Office of the Education Council Secretariat revealed that there were 7.2 million students in compulsory education out of total population 7.4 million people or 96.5 percent, which increased 2.0 percent from the academic year 2014 (Office of the Education Council Secretariat 2016) as shown in Figure 1: Population, number of students, students in formal and non-formal educations of academic year 2015.

Table 1. Population, Number of Students, Students in Formal and Non-Formal Educations of Academic Year 2015

\begin{tabular}{|c|c|c|c|}
\hline Level & Level & Level & Level \\
\hline Kindergarten & Primary school & Secondary school & High school \\
\hline $3-5$ years old & $6-11$ years old & $12-14$ years old & $15-17$ years old \\
\hline \multirow[t]{3}{*}{2.3 million people } & 4.8 million people & 2.6 million people & $\begin{array}{c}2.7 \text { million people } \\
72.7 \%\end{array}$ \\
\hline & & $88.3 \%$ & 2.0 million people \\
\hline & $100.9 \%$ & 2.3 million & ordinary Vocational \\
\hline $118.3 \%$ & 4.9 million & & $48.9 \% \quad 23.8 \%$ \\
\hline \multirow[t]{6}{*}{2.7 million people } & & & $0.2 \% 5,650$ people \\
\hline & & $0.3 \% 8,512$ people & $27.1 \%$ \\
\hline & & $11.4 \%$ & 0.7 million people \\
\hline & & 0.3 million people & \\
\hline & Population & & Uneducated children \\
\hline & Students in formal education & & $\begin{array}{l}\text { Students in non-formal } \\
\text { education }\end{array}$ \\
\hline
\end{tabular}

According to the education of Thai children in primary school, $100.9 \%$ of them were educated. The students in formal education in secondary level were $88.3 \%$, non-formal education $0.3 \%$, uneducated children $11.4 \%$. Students were in high school at $48.9 \%$, vocational college $23.8 \%$, non-formal education $0.2 \%$, uneducated children $0.7 \%$. Therefore, compulsory education in Thailand, it was noticeable that there were two periods that children were $100 \%$ educated: primary education. But during secondary school, some children were uneducated at $11.4 \%$, which was a small ratio comparing with the population in 2015. For further education of Thai children, it was found that there was a higher rate of admission to further education, as shown in Figure 2, the rate of education per student and university students classified by educational level in academic year 2015.

Primary School

Secondary School

High School
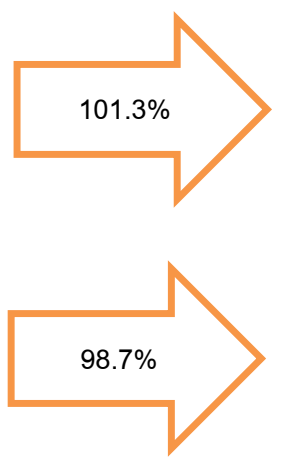

$95.0 \%$

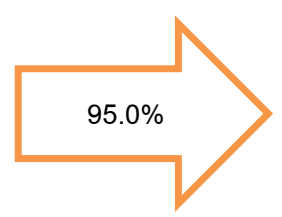

Secondary School

High School

University 
From figure 2, it was found that students who graduated from primary school in academic year 2014 continued their education in secondary school in academic year 2015 was higher at 101.3 percent, while students who graduated from secondary school in academic year 2014 continued their education in high school in academic year 2015 was higher at 98.7 percent. They continued education in ordinary field more than vocational field. In addition, students who graduated from high school in academic year 2014 continued their education in higher education in academic year 2015 was at $95.0 \%$ percent.

Based on this information, the education rate of students from compulsory education to continue their education in high school was in the ordinary field more than the vocational field. Also, it was found that the rate of continuing education in the university level is as high as $95 \%$, which was considered a high rate. This is in accordance with the data from the interview of students who passed the written exam and interview to be admitted to the Faculty of Education in Social Studies Program. It was found that all students who passed the written exam agreed that they decided to continue education at the university level because they realized and expected further education in order to develop themselves and the country, which their parents thought and believed so as well.

Nowadays, the education management in Thailand is in accordance with the National Education Act (Vol.3), B.E. 2553 (2010). The foundation for education should be provided from kindergarten, primary, secondary and higher level. The approaches for development must be prepared with a clear purpose leading to sustainable development, especially the higher education. From the study of the long-term Higher Education Plan 15 years Vol. 2, B.E.2551-2565 (2008-2022) of the Office of the Higher Education Commission. The goal is to raise the quality of Thai higher education, develop personnel to be higher quality and be able to work efficiently, develop potential of Thai higher education for knowledge generation and innovation, enhance the country's competitiveness in the globalization, support the sustainable development of local Thai communities by using the mechanism of good governance, develop personnel higher education and higher education network, adjust the learning infrastructure of students. The Thai Qualifications Framework for Higher Education (TQF: HEd) is set up to be used as a guideline for curriculum development and improvement, learning management, and quality of education management development to be able to produce quality graduates to support the standard of qualifications at the higher education level. The quality of graduates at all levels must meet the standard of learning outcomes set by the Commission of Higher Education covering at least 5 areas: morality and ethics, knowledge and intellectual skill, interpersonal skill and responsibility, numerical analysis skill, and communication and technology skill. For the disciplines that emphasize practical skills, the standard of the range learning outcomes is required. The management of social studies has to focus on practice, so the range of skills is important (Office of the Higher Education Commission 2009), which is necessary for the learner. The quality assurance (SAR) that assesses the quality of the professional field directly affect are Thai youth and graduates in the future. There will be changes in the dimensions of living, learning, family, and community. Student learning space in the form of experiential learning management for students should be increased to improve their quality of life as the concept of Keeves 1997 (keeves 1997). He mentioned about mind tools that people use in their quest for answers. The knowledge and understanding of many phenomena should be based on a learning management model that will help predict the consequences that can be logically proven and be able to create imagination and ideas for learners.

According to the approaches for educational management in Thailand, the curriculum of the Ministry of Education has been changed to keep up with the social changes affecting the world in an era of globalization. A new step in the transition from scientific advances requiring high-resolution and low-error data in the nanotechnology era. This causes the old paradigm of the old Thai education management to be transformed into a new paradigm. Early learning used teachers and textbooks as a learning center which are available in classrooms and textbooks. Regarding, teaching and learning paradigms, teachers only pass knowledge to learners. Learners often do not ask for knowledge other than the book or the teaching. Learners are afraid to ask or freely think of knowledge more than they have been taught. It is different from today that school have changed from construction to unlimited center. Instead, it connects teachers, students, and the community into a world treasury of knowledge. Teachers will transit from being a knowledge importer to supporters who assist students transform information into knowledge and apply knowledge into appropriate and practical tools. It is learning to create knowledge and to create a culture of searching. There is an evaluation based on reality including learning from service is an important element that focuses on promoting cognitive abilities, problem-solving skills, expressing the ability to work with others to prepare learners for internationalization. Therefor, these changes are related to the developed theories, concepts, and principles. They create a new paradigm comparing with many old paradigms. The primary goal of education is to learn about human being who can live in the modern world with quality while society is changing. Also, the educational paradigm has changed as well. The change in the expected conditions of education is using paradigms as a guideline for the 
development of educational management towards the set goals, which paradigm play a role as method, approach or a set of ideas and beliefs arising from the process of thinking, analysis, thinking, practice, and operational guidelines. These will be reviewd to be in line with the current and upcoming times and situations in a creative learning management model. Educational management in the field of social studies to develop and strengthen teacher professional competencies in five areas: citizen duty, religious and culture, history, economics, and geosciences. When extracting these knowledge, community information can be used as a base for the study of information and applied in the social studies teacher profession. Referring to Pittaya Wongkul on paradigm development in community-based learning management, the community has social capital, which means "value". Thai society has value which is the original capital that society has, whether its support, trust, reciprocity, and cooperation in various activities of the community. As a development based on one's own potential, social capital is therefore an important base for building a strong social relationship of the community on the foundation. Their roots affect the development of the overall nation leading to sustainable development.

The approaches the management of creative learning by professional teacher students can be utilized to benefit the local schools and can manage learning by using community-based learning resources. Therefore, it is important to strengthen the community as an important strategy for the development of Thai community and society towards a society of wisdom and learning. This is one of the important strategies for the development of Thailand as the 12th National Economic and Social Development Plan 2017-2021 has mentioed about the development approach to promote the strategy.

\section{Conclusion}

The preparing education for learners in the future must transform perspectives from the tradition paradigm to a new paradigm that puts the learner's world and the real world at the center of the learning process. A paradigm is a set of ideas and beliefs consisting of principles, objectives, procedures for learning management, measurement and evaluation, and important conditions for successful implementation of the paradigm. It is learning that goes beyond simple knowledge acquisition focusing on developing skill and attitude, thinking skill, problem solving skill, organizational skill, positive attitude, self respect, innovation, creativity, communication skill, values skill, technology, self-confidence, flexibility, motivation, environment awareness, and the ability to use knowledge creatively. It is an important and essential skill to prepare for the future. It is consider a challenge to develop for confronting the future world. A developed paradigm to apply to a learning activity using the community as a learning center for students to succeed in utilization. It will be recognized and used to further expand the effect of social studies teachers, while the population data from the Mano Population Survey Central Statistics Bureau of The Office of the National Economic Development Council was found that the annual rate of increase in each population from the census 1960 - 2010 has been steadily falling from 2.76 percent, 2.68 percent, 1.98 percent, 1.10 percent, and 0.69 percent, respectively. It is because of the effect of economic and social development, it is also the result of policies, planning and demographic projects since 1970. According to the Thai population data, there is a downward trend every year as a factor affecting the development of the country in all aspects as well as in terms of education, the number of applicants to be admited in higher education has decreased significantly among private institutions in Rajabhat groups in various fields. While in teaching professions among Rajabhat institutes, students who wish to further study have a high demand (Data from the Rajabhat Registration Promotion Office 2012-2017). For example of applicants of social studies teacher profession in academic year 2012 was 950 applicants, academic year 2013 was 743 applicants, academic year 2014 was 622 applicants, academic year 2015 was 568 applicants, academic year 2016 was 545 applicants and academic year 2017 was 467 applicants. When comparing data from both Songkhla Rajabhat University and the parties, the top field that applicants wish to study was Early Childhood Program, followed by Social Studies Program. According to the statistics on the birth of the population tended to decrease. It effected the number of applicants to decrease as well. The Social Studies has prepared for professional students, social teacher groups, throughout the five-year and four-year teacher curriculum production period. In addition, groups of students who are able to take the teacher admission exam and the students who find themselves weak on professional skills as teachers after graduate. They can develop themselves in other career paths.

\section{References}

Academic Department. (2009). Student-centered Learning Management. Bangkok: Thai Wattana Pich.

Klaus Meier. H. J. (1985). Education psychology. New York: Harper \& Row. 
Office of the Education Council Secretariat. (2016). Education Statistics of Thailand in Academic Year 2014-2015. Prikwan Graphic Ltd. Bangkok.

Office of the Higher Education Commission. National Standards Framework for Higher Education, B.E. 2552 (2009). Bangkok: Office of the Higher Education Commission (Copy).

Richardson virgimia. (1997). Constructivist teacher education; building new understanding. London: The Falmer Press

Rogers, C.R. (1969). Freedom to learn. Columbus. Ohio: Charles E. Merrill Publishing Company,

Steiner E. (1988). Methodology of theory building. Sydney: Ecology Research Associates.

Sumalee Chaicharoen. (2014). Teaching Design, Theory toward Practice. Khon Kaen: Faculty of Education, Khon Kaen University.

Thissana Khaemmanee. (2011). Teaching Science. Bangkok: Chulalongkorn University.

Vichai Panich. (2012). A way to create learning for students in the 21st century. Bangkok: Sodsri-Saritwong Foundation.

\section{Copyrights}

Copyright for this article is retained by the author(s), with first publication rights granted to the journal.

This is an open-access article distributed under the terms and conditions of the Creative Commons Attribution license (http://creativecommons.org/licenses/by/4.0/). 